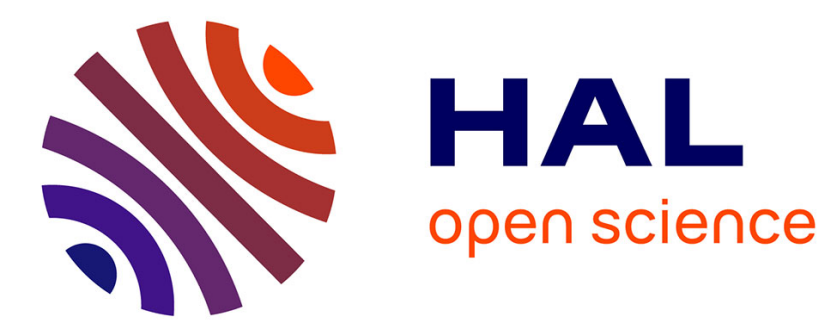

\title{
Social Policies in the World Bank
}

Anthony Hall

\section{To cite this version:}

Anthony Hall. Social Policies in the World Bank. Global Social Policy, 2007, 7 (2), pp.151-175. 10.1177/1468018107078160 . hal-00571802

\section{HAL Id: hal-00571802 \\ https://hal.science/hal-00571802}

Submitted on 1 Mar 2011

HAL is a multi-disciplinary open access archive for the deposit and dissemination of scientific research documents, whether they are published or not. The documents may come from teaching and research institutions in France or abroad, or from public or private research centers.
L'archive ouverte pluridisciplinaire HAL, est destinée au dépôt et à la diffusion de documents scientifiques de niveau recherche, publiés ou non, émanant des établissements d'enseignement et de recherche français ou étrangers, des laboratoires publics ou privés. 


\title{
Social Policies in the World Bank
}

\author{
Paradigms and Challenges
}

\author{
ANTHONY HALL \\ London School of Economics, UK
}

\begin{abstract}
A B STRACT Social policies in the World Bank have evolved into three conceptually and operationally separate agendas: social welfare, social protection and social development. Welfare services and basic human needs, as well as social protection in the form of safety nets and social safeguards, together form the mainstay of what is generally regarded within the organization as constituting social policy. Social development reflects a broader if more fragmented view of social policy. Bank specialists have recently sought to widen the definition of social policy beyond welfare and protection, building upon longstanding academic discourse in this field. However, in attempting to pursue a more holistic and over-arching vision of social policy for development, they are likely to encounter major internal obstacles. Meeting this challenge will not be facilitated by the Bank reorganization announced in June 2006, which may serve to restrict the independence and remit of environmental and social specialists.

KEYWORD social development, social policy, social protection, social welfare, World Bank
\end{abstract}

\section{Introduction}

Despite its pioneering role in promoting international development, the World Bank has not generally been considered a leading overt proponent of social policy. The word 'overt' is deliberately employed here because, to a greater or lesser extent and in a variety of ways, the institution has clearly exercised a significant influence on the design and execution of social policies in the South (Deacon et al., 1997; Yeates, 2001). Yet it is only relatively recently that the term 
'social policy' has entered the Bank lexicon. This delay should perhaps come as no surprise considering the institution's traditional mainstream emphasis on infrastructural investment and macro-economic growth. Yet if 'social policy' is conceptualized in broader terms than the conventional Organisation for Economic Co-operation and Development (OECD) definition of providing statutory social services, it is evident that a diverse policy-relevant social agenda has emerged within Bank operations over the past three decades. This has taken the shape, for example, of (1) investments in key social sectors such as health, education and pensions, (2) targeted anti-poverty programmes such as safety nets, (3) the use of operational tools such as social assessments, poverty and social impact analysis and poverty reduction strategy papers, and (4) social safeguards designed to mitigate the potentially harmful consequences of infrastructure projects. Whether applied via budget support through sector-wide loans (SWAPs) or through specific projects and programmes, social instruments with policy relevance may thus take various forms.

In this context, the article has three aims: (1) to disaggregate strands of 'social policy' (in broad terms) thinking and practice within the current work of the World Bank, (2) to consider what conceptual, operational and organizational factors underpin these divisions, and (3) to assess potential implications for the future of social policy within the Bank.

In World Bank operations, 'social development' has become common currency and now has its own Board-approved strategy, Empowering People by Transforming Institutions (World Bank, 2005a). At the same time, as noted earlier, social analysis at micro, sector and macro levels has become an integral part of Bank work. Yet the specific term 'social policy' has been employed infrequently. Related terms such as 'human development', 'social protection' and 'social safeguards' are employed instead. These labels reflect the historical accumulation of a diverse social agenda within the Bank during its lifetime, reflecting critical junctures in policy making. They refer to a range of social activities that have been developed in different (often competing) segments of the organization, each performing distinctive functions in response to specific operational needs and as the result of organizational restructuring.

\section{Social Policies in the World Bank: Evolving Agendas}

Three basic strands of social policy are observable in the work of the World Bank (illustrated in Figure 1). Two of these are well established (social welfare and social protection) while the putative third element (social development) is of more recent origin. They may be summarized thus:

- Social welfare. Following mainstream development traditions, social policy in the Bank is often equated with the provision of social welfare services in the areas of education, health, nutrition, population and social security 
including pensions. The underlying rationale is enhancing human capital to boost macro-economic growth, which has its intellectual origins in modernization theory. It also reflects the Basic Human Needs approach to poverty alleviation established in the 1980s (Stewart, 1985).

- Social protection. In the wake of structural adjustment and the move towards the construction of social safety nets targeted at the poorest groups, social policy in the Bank is increasingly seen as being synonymous with social protection. Although social safety nets have long formed part of social policy in OECD and other countries, they are becoming popular with the Bank and its clients as a tool for tackling absolute poverty. They include measures such as social funds and conditional cash transfer (CCT) programmes. This second broad category also embraces the Bank's safeguards policies (for example on environmental impacts, involuntary resettlement and protection of indigenous groups). Designed to minimize the potentially negative impacts of Bank-funded projects upon local populations, these safeguards are sometimes referred to internally as 'do-no-harm' social policies. For most Bank staff, therefore, social policy is reduced either to welfare and basic needs provision or the protection of vulnerable groups through safety nets and safeguards.

- Social development. There is, however, a third category of Bank activity that accounts for a major portion of Bank funding and which has major social ramifications. It includes substantial work programmes or clusters of projects around themes such as community-driven development, social accountability, conflict prevention, and participation and civic engagement, among others. This is a loosely grouped social agenda which has evolved incrementally in an ad hoc fashion as a result of internal restructuring and competition for resources rather than following any clear rational. The Social Development Strategy (World Bank, 2005a) represents an attempt to provide some coherence to this agenda. These three facets of Bank social policy will now be discussed in more detail.

\section{Social Policy as Welfare}

Arguably one of the major twin pillars of what many regard as the Bank's contribution to social policy is investment in education, health, population and nutrition, which falls under the Human Development network (Figure 1). Education and health investments commenced in the 1960s as part of the economic modernization framework, intellectually underpinned by human capital theory (Becker, 1964). During the presidency of Robert MacNamara (1968-81), a third of the Bank's loan portfolio by value was dedicated to antipoverty initiatives in rural development, health, education and population projects. However, these were still consistent with the Bank's mainstream focus on economic growth (Ayres, 1984). 


\section{WORLD BANK SOCIAL POLICIES}

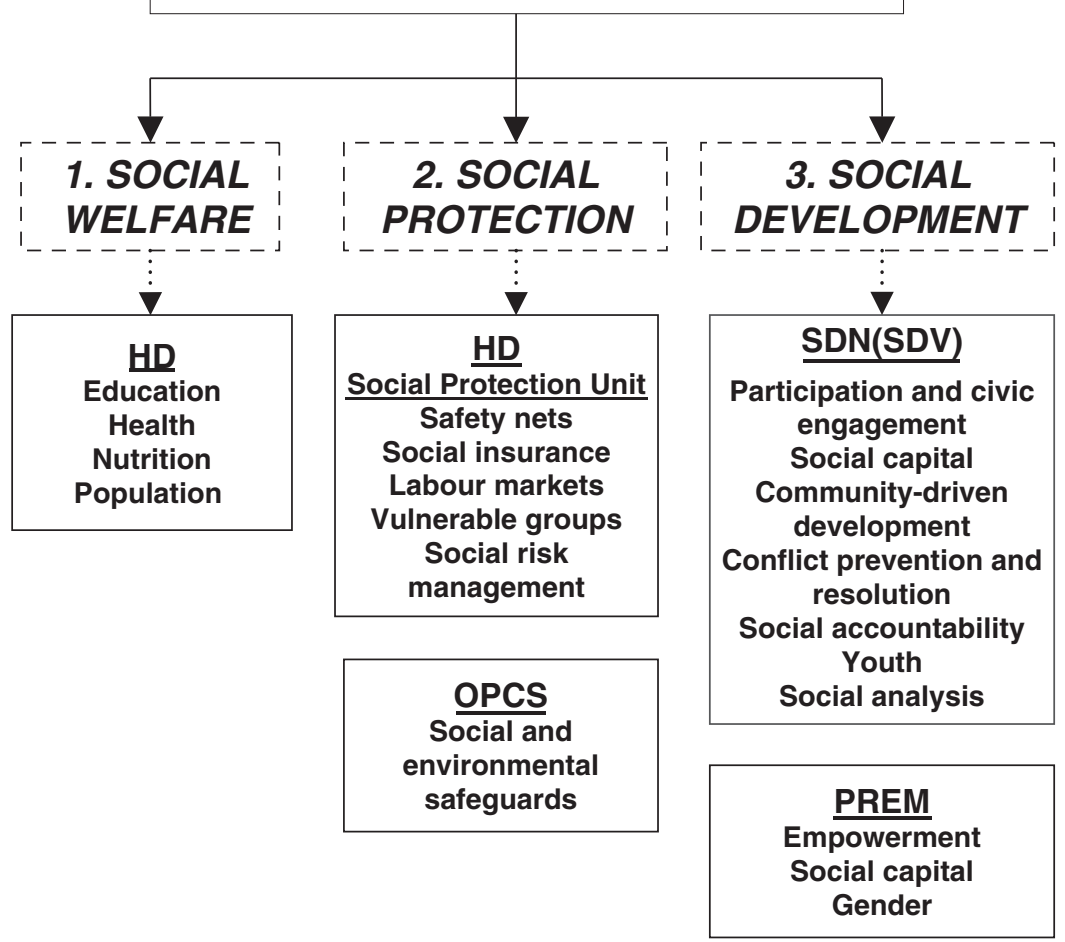

FIGURE I Dimensions of social policy in the World Bank

World Bank Thematic Networks (Vice-Presidencies)

HD Human Development

OPCS Operations Policy and Country Services

SDN Sustainable Development Network - formed in June 2006 by merging

Environmentally and Socially Sustainable Development (ESSD), including Social

Development (SDV), with the Infrastructure vice-presidency.

PREM Poverty Reduction and Economic Management

Under Tom Clausen (1981-6), influenced by the conservatism of Reagan and Thatcher as well as disillusionment within the Bank over the apparent failure of MacNamara's anti-poverty programme to produce visible results, the emphasis on direct poverty reduction through social investments temporarily diminished as the role of the private sector was heightened and economic growth was once again prioritized (Ayres, 1984). However, the momentum of support continued for pursuing short-term welfare objectives and investment in human resources with a poverty focus (for example through primary and basic education, primary health care and nutrition projects), which were seen as essential for supporting growth and productivity. Building upon the human capital concept of the 1950s and 1960s, it was argued that 
investment in education, health and other social sectors produced high rates of return. Meeting Basic Human Needs was thus a corollary to economic growth strategies as doubts over the validity of 'trickle down' assumptions were constantly raised (Stewart, 1985). These goals were reflected in the third World Development Report, which identified 'human development' as a process that could reconcile welfare and growth as complimentary rather than contradictory agendas (World Bank, 1980). ${ }^{1}$

Clausen's successor, Barber Conable (1986-91), oversaw a Bank 'rededication' to pro-welfare and anti-poverty measures in Bank policy (Kapur et al., 1997). Flying in the face of opposition from the US administration, the Bank drew up a new Core Poverty Program (CPP) to tackle hunger in Africa and to deal with the social costs of adjustment. Buttressed by support from UNICEF and the call for 'adjustment with a human face' (Cornia et al., 1987), the Bank focused on constructing 'safety nets' using social emergency programmes and social action funds. At the same time, the message was reinforced that investment in human resources through health, education and population programmes was good for growth. The Bank's 13th World Development Report (WDR) on the theme of Poverty focused on promoting the productivity of the poor while providing them with basic social services, especially education, complemented by programmes of targeted transfers and safety nets (World Bank, 1990). A decade later, the WDR on Attacking Poverty preached empowerment of the poor through decentralization in the implementation of social services such as health and education. This would, it was argued, make State and social institutions more responsive to the needs of the poor, while building assets and introducing insurance mechanisms and targeted transfers to offer protection against risks and shocks (World Bank, 2001).

Some middle-income countries such as Chile, Costa Rica, Taiwan and South Korea, have been comparatively successful in advancing the principle of more universal welfare service provision. Most nations in the South, however, are still characterized by limited access to poor quality services and selective benefits. This comprises a mixture of residual provision, focusing on social pathologies, together with incremental service expansion driven by the political demands of urban middle and organized working classes rather than broader social needs. In Brazil, for example, the social budget strongly subsidizes wealthier elite and middle-class groups through State funding for higher education and civil service pensions (Hall, 2003, 2006).

The welfare ethos of State provision was challenged in the 1980s by the New Right, which induced an ideological mistrust of government (Friedman and Friedman, 1980; Murray, 1984). The State was now portrayed as paternalist and repressive, its direct control to be reduced in favour of greater freedom of choice for individuals. Furthermore, it was seen as necessary to contain public spending and shift a larger share of the cost burden onto service consumers. To meet these two goals, economic liberalization and deregulation meant the growing privatization of public services along with reliance on the creation of 
markets and internal quasi-markets to boost efficiency in the allocation and spending of resources. The Bank played a leading role during the 1990s in pushing forward the 'Washington Consensus' package of privatization and state deregulation of welfare service provision (Williamson, 1990).

Yet market solutions in social provision have proved highly contentious. The charging of user fees in health and education, advocated by the Bank and other international organizations during the 1990s, has often been counterproductive and acted as a rationing mechanism that limits access by the poor. In the primary education sector, disquiet over the effects of privatization on access and the subsequent withdrawal of school fees on equity grounds has helped fuel a massive expansion in enrolments in Uganda and Malawi, for example, although improvements in education quality have lagged behind (World Bank, 2006a). Due to public resource constraints and fiscal reforms, private, out-of-pocket payments comprise a major source of revenue for health financing, $80 \%$ in the case of India, for example. However, user fee policies in the health sector are judged to have been a failure generally speaking as they are regressive and discriminate against the poor (Bhatia and Mossialos, 2004).

The privatization of pensions in developing countries, encouraged by the Bank from the 1980s, demonstrates a similar record. From 1984-2004, the Bank assisted 68 countries with pension reform through over 200 loan operations. A multi-pillar strategy was promoted based on a combination of publicly and, in particular, privately funded mandatory and voluntary plans (World Bank, 1994, 2000). Yet in the face of high costs, low returns and limited coverage, the experiment is now considered by even the Bank itself to have been a failure (Gill et al., 2005). A recent Bank evaluation admitted that over-preoccupation with fiscal sustainability had obscured poverty reduction and protection goals, and that this approach had not considered policies to protect those vulnerable elderly not covered by public pension schemes (World Bank, 2006b).

Of the three social policy related themes identified in this article, those welfare inputs provided through the Human Development (HD) network form the most prominent within the Bank's operations. In fiscal year 2005, it accounted for $13 \%$ of total Bank lending (US\$2.95bn), compared with $8 \%$ (US\$1.19bn) in 2000. Table 1 illustrates the steep rise in HD investments, annual spending having increased by $148 \%$ in the space of 5 years to 2005 . Budgetary constraints have led to a slight decrease in annual HD expenditure since the peak year of 2003 (US\$3.37bn). Of total 'social policy' spending within the Bank, HD accounts for 44\% (Table 1 and Figure 3). HD is responsible for $14 \%$ of the Bank's US\$95.4bn in net loan commitments, the second largest after Financial and Private Sector Development (Figure 4). In addition to its financial significance, the Human Development network commands a strong political position within the Bank. It is home to a large proportion of staff economists and enjoys a reputation for technical strength. 
TABLE I World Bank lending by social policy-related major themes, 2000-5 (US\$millions)

\begin{tabular}{lrrrrrr}
\hline Theme & 2000 & 2001 & 2002 & 2003 & 2004 & 2005 \\
\hline $\begin{array}{l}\text { Human } \\
\text { development }\end{array}$ & 1190 & 1134 & 1756 & 3374 & 3079 & 2951 \\
$\begin{array}{l}\text { Social protection } \\
\begin{array}{l}\text { Social } \\
\text { development }\end{array}\end{array}$ & 1895 & 1651 & 1086 & 2324 & 1577 & 2437 \\
$\begin{array}{l}\text { Total social policy } \\
\text { spending }\end{array}$ & 3885 & 1469 & 1385 & 1003 & 1557 & 1285 \\
$\begin{array}{l}\text { Total World } \\
\text { Bank lending }\end{array}$ & 15,276 & 17,250 & 19,519 & 18,513 & 20,079 & 22,307 \\
\hline
\end{tabular}

Source: World Bank (2005e: 57).

\section{Social Policy as Protection}

The second distinctive category of 'social policy' within Bank operations includes measures to protect the weak and vulnerable. This is accomplished either through (1) social investments carefully targeted at the poor or (2) environmental and social safeguard policies designed to mitigate the potentially harmful impacts of Bank-funded infrastructure projects. The first group of social investments falls largely under the Social Protection Unit, set up in 2001 within the Human Development network (Figure 1). This includes labour market interventions, natural disaster management, social risk mitigation, safety nets, vulnerability assessment and monitoring as well as social insurance and pensions.

Having emerged in the context of structural adjustment during the 1980s and 1990s, safety nets have become an increasingly popular policy instrument in the Bank. They now account for almost a quarter of the Bank's active social protection projects and total commitments of almost US\$6bn. ${ }^{2}$ They include cash and conditional income transfers, food programmes, price subsides and micro-credit as well as school vouchers and fee waivers for health care services. The Bank claims to have gone beyond mere social protection in its Social Risk Management framework, aiming to build livelihood capacity over the longer term. This involves three strategies to deal with risk and vulnerability (prevention, mitigation and coping) within a multi-institutional approach (World Bank, 2000).

The strength of the Social Protection (SP) portfolio within the Bank is illustrated by the fact that in 2005 it accounted for $36 \%$ of 'social policy' spending, having more than doubled in size since 2002 (Table 1 and Figure 2). However, this proportion has dropped slightly since 2000, when SP accounted for almost half of the total, and as HD has expanded in relative terms over the same period (Figure 3). In 2005, SP was responsible for $7 \%$ of 


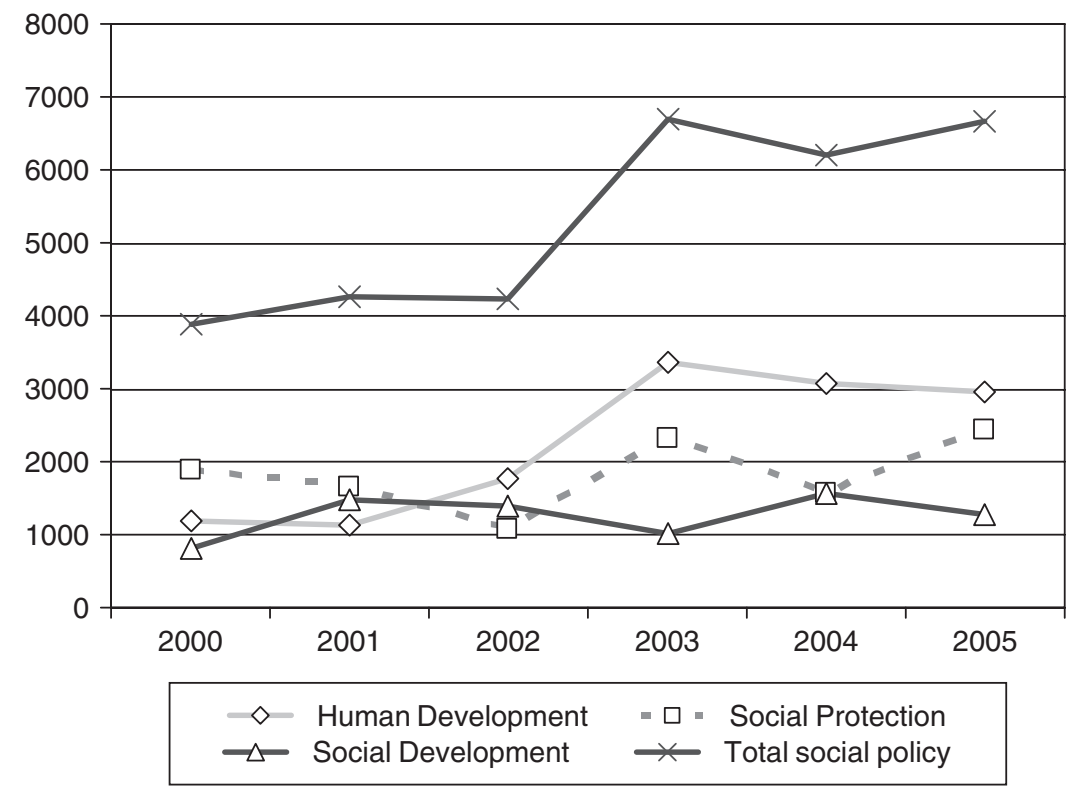

F I G U R E 2 Trends in World Bank lending for social policy-related themes, 2000-5 (US\$ millions) Source: World Bank (2005e: 57).

the Bank's active project portfolio of US\$95.4bn (Figure 4). In 2005 HD and SP together accounted for $21 \%$ of Bank lending.

Social protection has acquired its prominent place in the Bank's work programme largely as a result of having to deal with the consequences of economic stabilization and structural adjustment. Far from being self-rectifying under adjustment, as had originally been predicted, poverty and vulnerability were exacerbated in many countries and for many groups. Welfare provision was heavily compromised, with politically 'soft' targets such as health and primary education often bearing the brunt of spending cutbacks (GrahamBrown, 1991; Kanji and Manji, 1991). In policy making, emphasis was placed on the creation of safety nets using social funds to target scarce resources at poorer, more vulnerable groups (Narayan and Ebbe, 1997; Subbarao, 1997). The collapse of the Soviet Union and comprehensive social security schemes in the former communist countries, the East Asia crisis and economic problems in Russia and Brazil during 1997-8 led to the introduction of large-scale, targeted social protection measures with Bank assistance. Yet, as already noted, attempts to privatize social services and introduce user fees has met with very limited success.

Nowadays, CCT programmes have become increasingly popular with both the Bank and its client governments as a form of social protection. As far as the Bank is concerned, CCTs have several advantages. They allow the poor to 


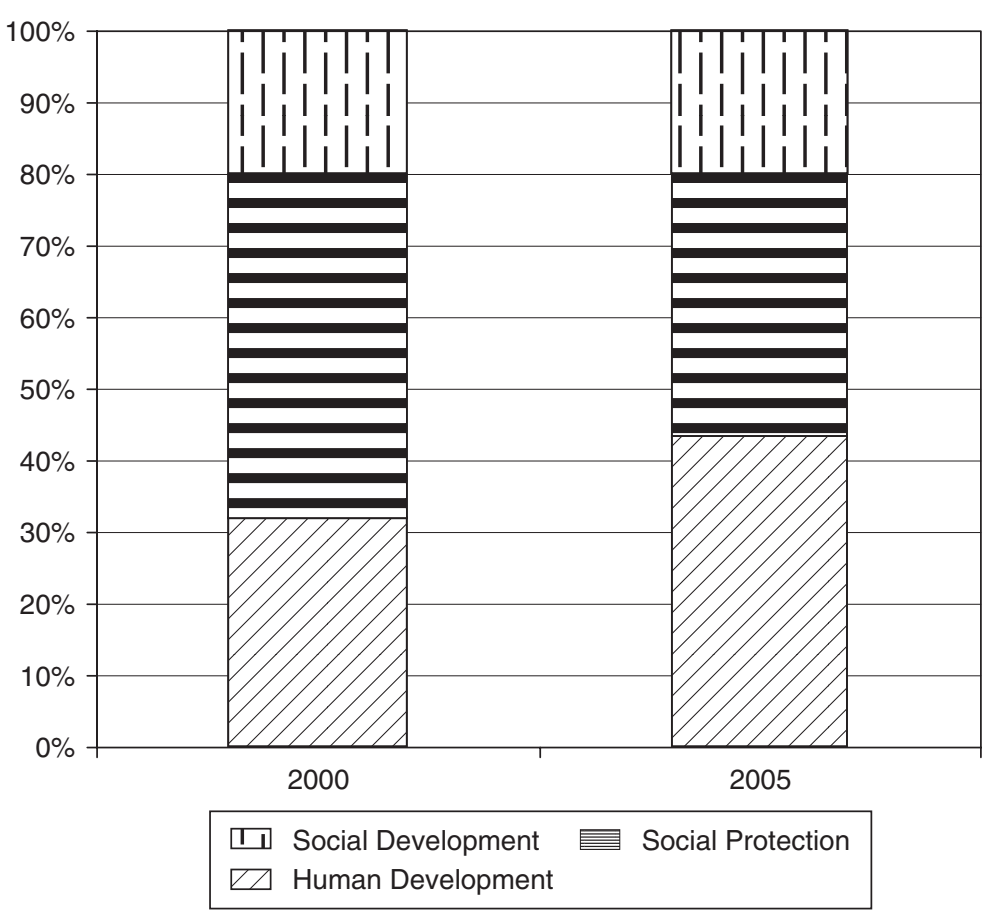

F I G URE 3 World Bank lending for social policy-related themes: 2000 and 2005 (\%) Source: World Bank (2005e: 57).

be targeted quite effectively and comparatively quickly, with benefits being directly channelled to vulnerable groups such as women and children, while generating additional benefits through education and health conditionalities (Coady et al., 2004; Rawlings, 2004). Evaluations of Mexico's Oportunidades programme (formerly known as PROGRESA), show that education, health and nutrition components have had a significant positive impact on welfare and human capital (Skoufias, 2005). CCT programmes are also attractive to portfolio managers due to the frequently large size of loans involved, since professional success is judged at least in part by financial turnover. Brazil's Bolsa Familia programme, for example, has been allocated total funding of US\$2.6bn by the World Bank and the Inter-American Development Bank.

CCTs are also popular with borrowers, not only because they boost government revenues, but also because they enable ruling parties to strengthen their political support at the ballot box, as illustrated quite clearly in the case of Brazil during the presidential elections of October 2006 (Coady et al., 2004; Hall, 2006; Pritchett, 2005). In many Latin American countries, CCTs are becoming a cornerstone of social policy, popular across the ideological spectrum due to their wide political appeal. ${ }^{3}$ Bank and borrowers thus have a mutual interest in adopting these social protection policies. Such a convergence of views on the 


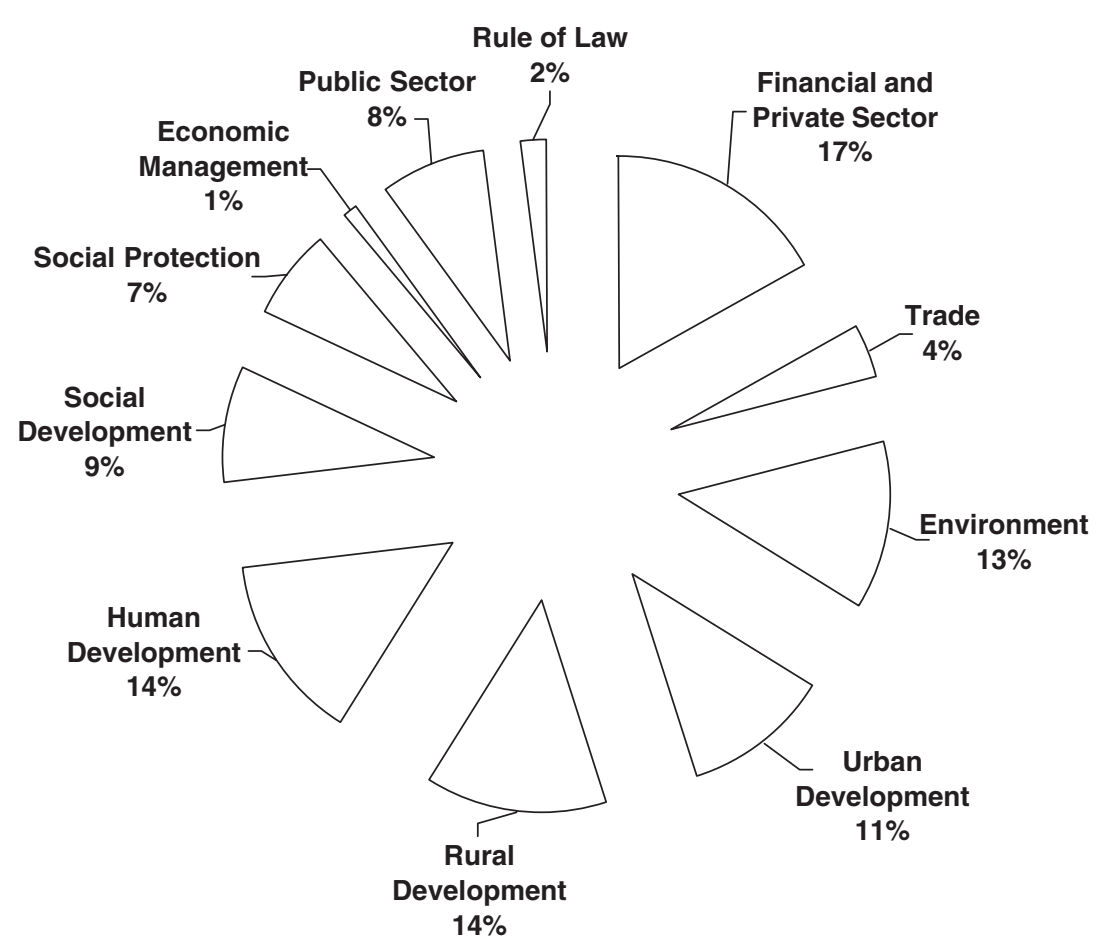

F I G URE 4 World Bank active project portfolio by theme, 30 fune 2005 (total commitments of US\$95.4 bn)

Source: World Bank (2005e) electronic version, accessed 4 April 2006, http://web.worldbank.org/WBSITE/EXTERNAL/EXTABOUTUS/EXTANNREP/EXTAN NREP2K5/0,,contentMDK:20655540 menuPK:1578540 pagePK:64168445 piPK:64168309 theSitePK:1397343,00.html

value of CCTs challenges the 'strong globalization' view of powerful international interests overriding national sovereignty, at least in this particular sector (Deacon et al., 1997; Yeates, 2001). This suggests that, for both reasons of economic austerity and political expediency, governments indeed know what they are doing in moving towards more selective, residual policies and perhaps away from the principle of universal provision.

Social safeguards may also be included in this second 'social policy' category since they too have been designed to protect vulnerable groups against the negative consequences of development policy, in this case the potential impacts of Bank-funded schemes. The first of the Bank's social safeguard policies were introduced in the 1980s to protect local populations such as the involuntarily displaced and indigenous groups against the adverse consequences of infrastructure schemes, typically dam and highway construction. ${ }^{4}$ Until mid-2006, social safeguards were the prime responsibility of the Social Development (SDV) department, part of the Environmentally and Socially 
Sustainable Development (ESSD) network, set up as a consequence of the 1997 Bank reorganization. Safeguards form one of the main business areas of cross-sector support to other departments for Bank anthropologists and similar social development specialists. No specific funding figures are available for safeguards policies but their application is strategically vital in project implementation and they enjoy a high profile, being subjected to considerable scrutiny from outside the Bank.

One unfortunate consequence of introducing such preventive measures is that safeguards-based social policy has, as noted earlier, become equated with a 'do-no-harm' approach to development. Social experts in this field are often informally likened within Bank circles to an internal police force employed to keep their colleagues under surveillance and minimize any potential damage that projects such as large-scale infrastructure development might cause. The perception that social scientists are a thorn in the side of those striving to implement mainstream Bank business in a timely fashion has been difficult to shake off and still persists quite strongly within the bureaucracy, as a recent evaluation demonstrated (World Bank, 2005b).

\section{Social Policy as Social Development}

The third pillar of social action within the Bank comprises a loosely articulated set of activities that falls mainly under the aegis of the Social Development (SDV) department, formerly housed within the Environmentally and Socially Sustainable Development (ESSD) network and, since June 2006, part of the Sustainable Development Network (SDN). However, the Poverty Reduction and Economic Management (PREM) network, which deals with mainstream macro-economic policy, has also acquired partial responsibility for several 'social' components that would under normal circumstances be the responsibility of SDV; for example, empowerment, social capital and gender (Figure 1).

Social aspects of Bank operations were first explicitly addressed in the early 1970s and the first rural sociologists were hired in 1974 with a view to improving project effectiveness. Early work focused on anthropology and project operations (Cochrane and Naronha, 1973), sociological variables in development (Cernea, 1985), participant observation (Salmen, 1987), involuntary resettlement (Cernea, 1988), indigenous peoples, women and institutions, natural resource management and social assessment (Perrett and Lethem, 1980). The 1987 Bank reorganization involved setting up Environment Units in each of the four regions, which incorporated social scientists as well as environmentalists. While this reflected growing general concern over the environment within the Bank, the restructuring was mainly in response to widespread adverse publicity received by the Bank within the USA and globally at the hands of a vigorous non-governmental organization (NGO) and media campaign following the catastrophic impacts of major projects, in particular the 
Northwest Amazon settlement project (Polonoroeste) in Brazil, among others, during the early 1980s (Redwood, 1993; Rich, 1994; Wade, 1997). The US Congress and US Treasury Department also played prominent roles in bringing about these changes. ${ }^{5}$ In 1993, a Social Policy and Resettlement Division was set up in the then Environmentally Sustainable Development (ESD) department with six staff and an anthropologist as division chief. Key Bank figures such as Michael Cernea, Scott Guggenheim, Gloria Davis and Robert Goodland drove forward the introduction of environmental and social safeguard policies while strengthening the use of social analysis in project design and appraisal (Davis, 2002).

A major watershed was reached in 1996 when newly appointed Bank President James Wolfensohn set up a Social Development Task Force to consider the role of social assessment in Bank operations. The Strategic Compact of 1997 involved management reorganization, decentralization of operations to country offices and the introduction of new communications technologies and staff training (Mallaby, 2004). A new Environmentally and Socially Sustainable Development (ESSD) network with its own vice-president was set up, including a central Social Development (SDV) department, and expertise also allocated to regional departments. As in 1987, reorganization a decade later was sparked in large measure by conflicts between the Bank and civil society organizations, partly as a consequence of the general 'Fifty Years is Enough' campaign and partly as a response to specific complaints at the subordination of environmental and social considerations in lending operations on a number of high-profile projects. ${ }^{6}$ The Bank's social development agenda also received a boost in 1999 from Wolfensohn's personal commitment to a 'Comprehensive Development Framework'. This stressed the importance of local participation, empowerment and an enhanced role for civil society, providing an appropriate context for the adoption of Poverty Reduction Strategy Papers in debt negotiations (Mallaby, 2004). Multi-million dollar trust funds to support social development projects were established by Japanese and European donors that provided additional funds to support the social development portfolio.

These changes helped to strengthen the role of 'social' expertise within the organization. From just a handful of social scientists employed in the early 1990s, a decade later the picture had changed considerably. By 2002, some 200 social development professionals were employed by the Bank either as staff or short-term consultants with another 250 or so Bank staff holding postgraduate degrees in non-economic social sciences (World Bank, 2005b). However, although this expansion in social expertise mirrors the growth in Bank lending, social experts are still relatively few in number compared with staff economists, especially in country offices.

This steady expansion is highly significant in operational terms, but there is still no single, commonly accepted definition in the Bank of what constitutes 'social development'. The social development portfolio has grown in a largely 
incremental manner, and perhaps this was inevitable given the eclectic nature of the subject and the historical context within which it evolved. According to the Bank's own evaluation, the organization's social development work 'is often characterized by what it does, rather than what it is', and it remains a 'fuzzy concept' (World Bank, 2005b: xiv, 2). Surveys have revealed that many SDV staff themselves do not consider the group's goals to be well defined. The SDV work programme falls into several major and evolving 'business lines', comprising clusters of projects around social themes that have been nurtured since the 1990s. This very mixed group includes community-driven development (CDD), participation and civic engagement, culture, indigenous peoples, conflict prevention and reconstruction, youth, and social accountability. In addition, as already noted, SDV provides social analysis inputs through a range of tools applied at project, sector and (more recently) at country levels, delivered largely as cross-sector support to other country and thematic departments (Poverty Reduction Strategy Papers, Poverty and Social Impact Analysis, ${ }^{7}$ Country Social Analysis, ${ }^{8}$ etc.). At the same time, however, SDV itself has only a very small free-standing project portfolio of its own (World Bank, 2005b). This limited 'ownership' has, according to some internal observers, contributed to the political vulnerability of SDV within the Bank's hierarchy.

Yet this social 'pillar' has collectively become involved in an increasingly large proportion of the Bank's lending portfolio. In the 1980s, investments with some support for social development were responsible for just $5 \%$ of lending, rising to $15 \%$ by 1994 (World Bank, 2005b). From 2000 to 2005, Social Development saw its lending increase by $38 \%$, from US $\$ 800 \mathrm{~m}$ to US\$1285m (Table 1). As shown in Figure 3, its share of the current 'social policy' agenda in the Bank (21\%) remains significantly lower than either Human Development (44\%) or Social Protection (36\%). However, as demonstrated in Figure 4, within the Bank's total active project portfolio, Social Development fares relatively well at 9\%, compared with HD (14\%) and SP (7\%).

Yet despite this expansion of budgets and personnel, the 'social' presently seems to be in a similar position to that occupied by the 'environmental' in the early 1980s within the Bank. Although social issues are highlighted as critical and much progress has been made in carving out a social agenda, the 'social' has not yet entered the mainstream of Bank operations. Social assessment of projects, for example, unlike environmental assessment, is not mandatory unless safeguard policies such as those for resettlement and indigenous peoples are triggered. ${ }^{9}$ In all other projects, decisions whether to include social analysis are taken largely at the discretion of team leaders, as had been the case with environmental screening before 1987. Decisions whether to adopt non-mandatory procedures are conditioned by factors such as the task manager's appreciation of their importance, budgetary and personnel constraints as well as the assessment of risk in terms of potential internal repercussions. This is despite the now widely accepted positive association between the incorporation of social 
dimensions and subsequent project performance (Cernea, 1985; World Bank, 2005b).

There are many reasons for this state of affairs. In addition to the dominance of macro-economists within the Bank there is, as already noted, a widespread perception that non-economic social scientists (especially anthropologists and sociologists) perform essentially policing or remedial roles. They are often still seen as something of a hindrance to the institution's 'real' business of development, with objections on social grounds only serving to slow down the process of loan approval and disbursement. There is thus a clear tension in Bank operations between the desire for quantity (i.e. project turnover, the imperative to spend allocated funds speedily and present projects for Board approval in a timely fashion) on the one hand and, on the other, the need to improve quality (i.e. minimizing negative social impacts and improving project fit). While Bank managers tend to prioritize project disbursements and financial turnover, social development specialists have to counterbalance this with the considerations of quality assurance and safeguards. In the process, however, this often creates a negative internal backlash.

Furthermore, the Bank's internal labour market mechanism does not encourage technical staff to be outspoken, quite the contrary. Apart from departmental and sector managers who are wholly or partially paid for through guaranteed 'core' funding, technical specialists are obliged to sell their 42 staff weeks a year against specific projects (each with its own budget code), whether operational or research. Task managers are reluctant to purchase the services of those with a reputation for being 'awkward' or 'difficult'. This is especially true once a project has passed the concept phase and is under preparation. A task manager's kudos is measured via the efficiency with which he or she can get projects approved by the Board, not necessarily in terms of project quality. Objections on social grounds can increase operational costs and cause delays in implementation. Professional survival in the Bank depends on maintaining one's marketability. With no guaranteed funding, a social specialist who cannot pay his or her way enjoys extremely poor job prospects in the Bank. This vulnerability has been reinforced by the growing tendency to hire social specialists on short-term, temporary contracts, which offer even less stability and make staff even more cautious, inducing much self-censorship.

There are other reasons for the sometimes indifferent impact of social experts in the Bank. In spite of the increased numbers of social scientists among Bank staff, there are still far too few to do justice to the potential workload. The services of social specialists either from SDV (at the 'centre') or the country departments (in the 'regions') are in constant demand to provide cross-support to projects in all divisions. This skills shortage is especially marked in Bank field offices in country and task teams. Here, there tends to be a strong reliance on short-term consultants to provide necessary social inputs but it is debatable whether these have the same clout as internal contributions that can be followed through by permanent staff. 
A major contributory factor that works against social mainstreaming, however, has its origins in the 1997 organizational restructuring of the Bank, mentioned earlier. This introduced a cross-cutting matrix system involving thematic and regional networks. Operations staff are generally 'mapped' to both a thematic group (such as HD, PREM or SDV) as well as to a region (Latin America, Africa, etc.). This has resulted in the institutional separation of social concerns among three vice-presidencies; namely, HD, PREM and ESSD (now merged into the SDN). With the transfer in 2006 of responsibility for social safeguards from SDV to yet another vice-presidency for Operations Policy and Country Services (OPCS), the social agenda now cuts across four separate Bank networks (Figure 1).

The bureaucratic separation of social policy concerns is reinforced by both conceptual and operational divisions. Conceptually, social investment is seen within HD both in terms of supporting macro-economic growth and providing social protection to the poor and vulnerable. To a large extent, this is also the view within PREM with its overriding concern for macro-economic growth and poverty alleviation. In principle, the Bank's social protection policies have evolved considerably and now go well beyond the construction of temporary safety nets to incorporate risk prevention and mitigation strategies that strengthen people's longer-term capacities to ward off poverty and expand their opportunities (World Bank, 2000, 2005c). Yet in practice social protection policies, which account for about a third of the 'social' agenda Bank budget, are still heavily characterized by measures to safeguard incomes and consumption through measures such as conditional cash transfers rather than being instruments for encouraging longer term social investment (Britto, 2005; Hall, 2006). SDV, in contrast, tends to view social investments as vehicles for advancing not just material but also non-material progress measured in terms of indicators such as participation and empowerment, cultural integrity, social integration, social accountability and citizenship rights. However, the sheer breadth, diversity and somewhat eclectic nature of the SDV social agenda makes it difficult to encompass all aspects within a clear, single definition, despite the attempt to formulate a Social Development Strategy (World Bank, 2005a).

Thus, in the eyes of most Bank professionals, welfare and protection comprise the organization's contribution to what is considered mainstream 'social policy' within the organization. In this view, the 'social' components of development are reduced in the main to deliverable goods and services such as welfare sector investments or risk-mitigating and targeted interventions. This dominant perception is clearly demonstrated for example in the Bank's Country Assistance Strategy (CAS) documents, which regularly map out strategic priorities and plans for Bank operations in client countries. Here, social policy is invariably perceived as being synonymous with the provision of social services and safety nets, with a growing enthusiasm for conditional cash transfer schemes. There is little attempt to systematically harmonize and 
integrate wider social development actions alongside and as an integral part of the process of macro-economic development (Midgely, 1995). The third branch of 'social development' remains highly fragmented, lacking in conceptual coherence and politically vulnerable within the Bank.

Given the organizational separation among networks, matched in some measure by different intellectual understandings of what constitutes 'social policy' in the Bank, it is inevitable that significant constraints on operational cooperation should appear. Competition over access to financial and staff resources will flourish (the infamous 'turf wars'), especially where there are few if any incentives that encourage cross-departmental collaboration. For example, SDV and PREM have been known to compete vigorously over the 'ownership' of social business lines, including the right to lead in the implementation of anti-poverty instruments such as Poverty Reduction Strategy Papers (PRSPs) and Poverty and Social Impact Analyses (PSIAs), gender analysis and civil society policy. The fact that a department's kudos is judged by the size of its own-managed portfolio rather than by its participation in cross-sector collaboration, even when the latter can be measured, leads to open competition over project ownership. Social development specialists resent the fact that their cross-sector inputs to projects are often 'hidden' in project budgets 'owned' by another (lead) department and are not given due acknowledgement. Such internal progress indicators as portfolio project size and financial turnover strongly influence staff promotion prospects, serving to reinforce interdepartmental competition further still.

\section{FUTURE CHALLENGES}

The social dimensions of development have been addressed by the Bank in a variety of ways and in response to many stimuli, both internal and external to the institution. This diversity is reflected in the range of social policies pursued and their spread across the organization, leading to a high degree of staff frustration at the lack of cross-sector collaboration and frequent competition, even outright conflict, over access to financial and human resources. This fragmentation of social agendas has provoked a rethink among social scientists concerned with reaching a new understanding of what should be regarded as 'social policy' in the 21 st century. Such preoccupations generated a major Bank conference in December 2005 to explore 'New Frontiers of Social Policy', which brought together a wide range of development professionals and academics. Its concluding statement declared that, ' ... social policy should not fall into the trap of one-size-fits-all prescriptions ... [and that we must] ... augment existing social policies by greater attention to employment (livelihoods), social integration and institutions' (World Bank, 2005d: 1). Indeed, this message rather belatedly reflects long-standing concerns outside the Bank in academia on the limited relevance of the OECD social policy model for developing countries and of the need for a more holistic view of human welfare needs. 
State welfare programmes in Latin America, for example, have been heavily criticized for reinforcing existing economic and social inequalities and doing little to promote redistribution or growth (Abel and Lewis, 2002). It is increasingly recognized in policy circles that social provision can be met through a variety of statutory and non-statutory means and via a range of institutions and actors at all levels of society from the household and community through to local, regional, domestic and international arenas. Academic social policy specialists have for some time been delivering this message (De Haan, 2000; Devereau and Cook, 2000; Hall and Midgley, 2004; Kabeer, 2004; Kennett, 2004; Institute of Development Studies [IDS], 2006). At the same time, the UN has also underscored the need for a wider approach through its research programme on 'Social Policy in a Development Context' (Mkandawire, 2004). The notion of 'welfare regimes' attempts to capture diverse paradigms through which needs in developing and transition countries are met by combinations of support through the State, market and community (Gough and Wood, 2004).

In academic and practitioner circles, and more recently within the Bank itself, initiatives are thus underway to extend the boundaries of social policy. In a developing country context, for example, it is argued that social policy should be more clearly linked to promoting economic development. Welfare developmentalism was strong in Germany, Sweden and Finland, where social insurance and investment schemes were designed to stimulate economic growth. The experiences of South Korea and Taiwan as well as Singapore and Hong Kong, which successfully developed and applied broad-based social policies, show that such a paradigm is valid and feasible to apply, albeit under special circumstances that may not be easily replicable elsewhere (Kwon, 2004).

One attempt to link social policy with economic development in the South has revolved around the concept of livelihoods. The Department for International Development (DFID)-funded 'Social Policy Research Programme' at the IDS, for example, has adapted the Sustainable Livelihoods approach to focus on people's livelihood strategies at different levels, analysing the 'broader institutional configuration of social provisioning which prevailed in different contexts and ... the extent to which it addressed the needs of the poor' (Kabeer, 2004: 3). It distinguishes between three 'social' domains; reproduction of life, reproduction of labour and reproduction of society. The biological and social reproduction of human beings embraces social policy as the provision of care services. Labour reproduction involves boosting economic productivity through health and education investments. This wider vision implies moving away from seeing social protection as simply a short-term welfare measure and towards a longerterm security perspective, involving livelihoods strengthening and the adoption of a rights-based approach (IDS, 2006). In a similarly broad fashion, Moser (2006) has developed an assets-based approach that aims to place social policy in the mainstream of poverty reduction debates.

The third dimension outlined in the IDS schema expands the remit of social policy to the macro and global levels. Reproduction of societal relations relate 
to the ideological and material conditions that form the basis of society, embracing 'the full range of institutional structures within a society [and implying a] broad understanding of "the social" as an aspect of development policy'. This approach to social policy 'detaches it from its moorings in particular sectors, programmes and projects and widens it to encompass the purposive efforts made by a range of public actors in a society, guided by some vision of "the social", to influence the processes by which life, labour and social relationships are reproduced within that society' (Kabeer, 2004: 10-11).

Consonant with this broader vision, the Bank's concept note for Arusha declared that: 'A more holistic approach to social policy in development contexts, where markets are grossly imperfect and labor markets often incomplete, would seek to promote policies, institutions and programs that balance a concern for equity and social justice with the concern for economic growth.' Social policy is defined as, 'public policies aimed at three levels: promoting equality of opportunity to benefit individuals (micro-level), equality of agency and institutional reform to benefit groups (meso-level), and horizontal and vertical social integration to benefit society (macro-level)', which would seek to 'offset inequities in asset endowment with equitable opportunities for asset creation and livelihoods' (Dani, 2005: 2-3).

It remains to be seen whether macro social policy that incorporates and builds upon broader notions of social development will take hold in the World Bank. However, in pushing forward this agenda, if indeed it does go forward, the Bank faces a number of challenges; these are conceptual, operational and political in nature. The first challenge is to overcome the narrow conceptualization of social policy as being limited to welfare services and social protection. This would entail close collaboration between the Bank and the academic community to define a framework capable of embracing these paradigms within a wider view that links social policy to livelihoods, well-being and economic development more generally. Many staff would resist the internalization of such ideas on the grounds that it is not within the Bank's remit and that the institution should limit itself to its conventional project portfolio. Furthermore, with the recent emphasis on infrastructure investments in official declarations under the new presidency, such 'soft' social concerns seem even less likely to command either political legitimacy or budgetary allocations.

Yet the conceptual challenge, while formidable, is in some respects the least difficult obstacle to overcome. Even if a mutually acceptable definition of social policy is indeed eventually reached, it will amount to little unless it is able to inform Bank operations. Welfare service provision and social protection are relatively easy to define and implement within the Bank's present organizational set-up and both enjoy strong internal political support. The institutional separation of responsibilities for these areas sets out a fairly clear division of labour and delineation of turf boundaries, despite some encroachment. However, this also leads to internecine conflicts and a lack of active collaboration among 
departments with different social agendas as they compete internally for scarce human and financial resources in the struggle for kudos and internal authority.

The challenge, therefore, would be to find ways of facilitating cross-sector collaboration within an overarching social policy framework. This would necessarily involve a degree of institutional restructuring together with a reexamination of incentives relating to allocation of funding, to staff promotion prospects and employment security, and to other matters that could help to foster a more collaborative work environment. Paradoxically, however, recent surveys show that the majority of Bank staff working with social issues remain firmly opposed to the suggestion that groups should be merged to facilitate integration of social policy agendas. This negative attitude is attributed variously to 'change fatigue', to a general lack of credibility in Bank capacity to get the structure right, and to the popular perception that economists will always predominate in Bank business no matter what organizational changes are made (World Bank, 2005b).

\section{Conclusion}

Even if a greater measure of conceptual and operational integration and collaboration were possible in theory among the diverse arms of social policy within the Bank, there remains a major practical obstacle to social policy mainstreaming in the organization. Assuming that a more appropriate social policy framework was defined, its effective implementation through Bank operations would be contingent not just upon appropriate changes in organizational and incentive structures, although these alone would require a radical rethink. Progress would, even more critically, be contingent on there being clear political backing for strengthening and integrating the Bank's social agenda more systematically into mainstream operations.

However, the Bank reorganization announced in June 2006 does not augur well for such change. To recap, the ESSD vice-presidency was abolished and the network merged with Infastructure (INF) to form a new SDN. At the same time, the environmental and social safeguards teams (in ENV and SDV) were transferred from the former ESSD to a separate vice-presidency, OPCS. The then bank president Paul Wolfowitz declared that, 'The purpose of consolidating these two networks is to mainstream environmental issues, improve synergies, better integrate core operations, and ensure that we strengthen our focus on sustainability as we increase our investment in infrastructure' (World Bank, 2006c: 1).

The brief but pointed reference to infrastructure in this statement is significant. It reflects a feeling among some Bank staff that the institution should return to its 'core' values of promoting economic modernization above all else. Many argue that such a new emphasis would more accurately reflect client country demands for heavy investment as a precursor for growth. It is 
also the product of disillusionment in some quarters with the record of 'softer' social investments in supporting the development process. Indeed, this discourse is reminiscent of that heard during the early 1980s when MacNamara's poverty agenda was eclipsed under Clausen by the return to a focus on economic growth.

It is a moot point whether this most recent reorganization and emphasis on infrastructure has been influenced by US foreign policy objectives, with a possible desire to redirect Bank investments into eventual post-war reconstruction efforts (in Iraq or Afghanistan, for example). The infamous debacle involving Bank chief economist Joe Stiglitz, and Ravi Kanbur, director of the WDR 2000, who both resigned in protest at alleged external 'interference' by the US Treasury, suggests that such a geo-political link is not outside the realms of possibility. ${ }^{10}$ Indeed, as noted earlier, it is well known that pressure from the US Treasury was a major factor in persuading the Bank to introduce reforms in its environmental procedures and organizational structure from 1987.

Yet, while the full implications of these organizational changes will take time to fully reveal themselves, outside observers have expressed serious concerns that they might weaken environmental and social considerations, including safeguards, and subsume them to the interests of infrastructure investments (Bretton Woods, 2006). Under such circumstances, it is difficult to imagine how a social policy agenda could grow within the organization, at least for the foreseeable future. Indeed, it seems even less likely now than it did a few years ago that preconditions exist for the expansion and consolidation of social development and social policy within the World Bank.

\section{ACKNOWLEDGEMENTS}

Thanks are due to Professor James Midgley and to three anonymous reviewers for their valuable comments on an earlier version of this article. The author spent two years (2003-5) on secondment to the World Bank as a social development specialist.

NOTES

1. During the 1980s under adjustment, welfare spending was doubly rewarding. 'Killing two birds with one stone, social service projects were discovered to be a powerful tool for the occasion: they served the adjustment, and thus the productivity and growth objective; and they served the equity and poverty objectives.' (Kapur et al., 1997: Vol. 1, 349).

2. Projects and Operations data, World Bank, April 2006.

3. Apart from Brazil, CCT programmes have been introduced in Mexico, Chile, Colombia, Nicaragua, Argentina and Ecuador (Rawlings, 2004).

4. The 10 safeguard policies now include environmental assessment, natural habitats, pest management, involuntary resettlement, indigenous peoples, forests, safety of dams, cultural property, projects in international waterways and projects in disputed areas. 
5. Approved in 1981, Polonoroeste demonstrated such a catalogue of errors and generated such protest that in 1985 the mid-term review recommended suspension of loan disbursements. These criticisms were made in the context of a much wider, global wave of concern during the late 1980s over issues of environmental management and sustainable development. Advocacy NGOs in the USA were instrumental in placing evidence of the Bank's poor record on environmental and indigenous affairs before key congressional committees in 1983, culminating in a list of recommendations calling upon the Bank and counterpart organizations to strengthen their environmental (including social) procedures. In addition, there was strong criticism from the powerful Senate Appropriations Subcommittee on Foreign Operations. Most crucially, however, the US Treasury under James Baker insisted that the Bank should 'clean up its act' as a precondition for approval of an International Bank for Reconstruction and Development (IBRD) capital increase and IDA replenishment (Wade, 1997).

6. These included the Sardar Sarovar dam project in India, the Chonoy dam in Guatemala and the Bulyanhulu gold mine in Tanzania. Another case in point was the Itaparica hydropower scheme in Northeast Brazil, which was reformulated to allow for comprehensive resettlement provision following massive local and international protests (Hall, 1994; Wade, 1997).

7. Poverty and Social Impact Analysis (PSIA) analyses the distributional impact of policy reforms on the well-being or welfare of different stakeholder groups, with particular focus on the poor and vulnerable. It plays a growing role in the elaboration and implementation of poverty reduction strategies in developing countries. The Poverty Reduction Strategy Paper (PRSP) is designed to outline poverty reduction goals as a condition of debt relief provided under the enhanced Highly Indebted Poor Countries (HIPC) Initiative.

8. The Country Social Analysis (CSA) takes a broader view of the social, economic and political context of development within specific countries in order to inform country operations and provide guidance on investment priorities.

9. Environmental review and clearance procedures became mandatory for all Bank projects in 1987, and a portfolio of 'environmental' projects was established.

10. Chief economist Joe Stiglitz and Ravi Kanbur, director of the World Development Report 2000, resigned (in 1999 and 2000 respectively) in protest at alleged intervention by the US Treasury to influence the content of the WDR as well as other Bank policy statements concerning the relative weight of civil society/anti-poverty vs economic development/free market messages and priorities (Wade, 2001, 2002).

\section{REFERENCES}

Abel, C. and Lewis, C. (2002) Exclusion and Engagement: Social Policy in Latin America. London: Institute of Latin American Studies, University of London.

Ayres, R. (1984) Banking on the Poor: The World Bank and World Poverty. Cambridge, MA: MIT Press.

Becker, G. (1964) Human Capital. New York: Columbia University Press.

Bhatia, M. and Mossialos, E. (2004) 'Health Systems in Developing Countries', in

A. Hall and J. Midgley (eds) Social Policy for Development (pp. 168-204). London: Sage. Bretton Woods (2006) 'Sustainability Dismantled', Bretton Woods Project, 28 June.

Britto, T. (2005) Recent Trends in the Development Agenda of Latin America: An Analysis of Conditional Cash Transfers. Manchester: Institute for Development Policy and Management, University of Manchester. 
Cernea, M. (ed.) (1985) Putting People First: Sociological Variables in Rural Development. New York: World Bank/Oxford University Press.

Cernea, M. (1988) Involuntary Resettlement in Development Projects: Policy Guidelines in World Bank-Financed Projects. Washington, DC: World Bank.

Coady, D., Grosh, M. and Hoddinott, J. (2004) Targeting of Transfers in Developing Countries: Review of Lessons and Experience. Washington, DC: World Bank.

Cochrane, G. and Naronha, R. (1973) A Report with Recommendations on the Use of Anthropology in Project Operations of the World Bank Group. Washington, DC: World Bank.

Cornia, G., Jolly, R. and Stewart, F. (1987) Adjustment with a Human Face. Oxford: Clarendon.

Dani, A. (2005) 'Concept Note', paper presented at the Conference on New Frontiers of Social Policy: Development in a Globalizing World, Arusha, Tanzania, 12-15 December.

Davis, G. (2002) A History of the Social Development Network in the World Bank, 1973-2002. Washington, DC: World Bank.

Deacon, B., Hulse, M. and Stubbs, P. (1997) Global Social Policy: International Organizations and the Future of Welfare. London: Sage.

De Haan, A. (2000) 'Components of Good Social Policy: Lessons Emerging from Research', mimeo., SDA Annual Workshop. London: DFID.

Devereau, S. and Cook, S. (2000) 'Does Social Policy Meet Social Needs?', IDS Bulletin 31(4): 63-73.

Friedman, M. and Friedman, R. (1980) Free to Choose: A Personal Statement. New York: Avon.

Gill, I., Trueman, P. and Yermo, J. (2005) Keeping the Promise of Social Security in Latin America. Washington, DC: World Bank.

Gough, I. and Wood, G. (eds) (2004) Insecurity and Welfare Regimes in Asia, Africa and Latin America. Cambridge: Cambridge University Press.

Graham-Brown, S. (1991) Education in the Developing World: Conflict and Crisis. London: Longman.

Hall, A. (1994) 'Grassroots Action for Resettlement Planning: Brazil and Beyond', World Development 22(12): 1793-809.

Hall, A. (2003) 'Education Reform in Brazil under Democracy', in D. Kinzo (ed.) Brazil Under Democracy: Economy, Polity and Society Since 1985 (pp. 269-87). London: Institute of Latin American Studies, University of London.

Hall, A. (2006) 'From Fome Zero to Bolsa Familia: Social Policies and Poverty Alleviation under Lula', Fournal of Latin American Studies 38(4): 689-709.

Hall, A. and Midgley, J. (2004) Social Policy for Development. London: Sage.

Institute of Development Studies (IDS) (2006) 'Looking at Social Protection through a Livelihood Lens', IDS in Focus 1(May).

Kabeer, N. (2004) 'Re-visioning "the Social": towards a Citizen-centred Social Policy for the Poor in Poor Countries', IDS Working Paper No. 191. Sussex: IDS.

Kanji, N. and Manji, F. (1991) 'From Development to Sustained Crisis: Structural Adjustment, Equity and Health', Social Science and Medicine 33(9): 985-93.

Kapur, D., Lewis, J. and Webb, R. (eds) (1997) The World Bank: Its First Half Century, 2 Vols. Washington, DC: Brookings Institution Press.

Kennett, P. (2004) 'Introduction: The Changing Context of Comparative Social Policy', in P. Kennett (ed.) A Handbook of Comparative Social Policy (pp. 1-7). Northampton, MA: Edward Elgar.

Kwon, H. (2004) 'Review Article: Social Policy and Development in Global Context', Social Policy and Society 4(4): 467-73. 
Mallaby, S. (2004) The World's Banker. New York: Penguin.

Midgley, J. (1995) Social Development: The Developmental Perspective in Social Welfare. London: Sage.

Mkandawire, T. (ed.) (2004) Social Policy in a Development Context. Basingstoke: Palgrave Macmillan.

Moser, C. (2006) 'Assets, Livelihoods and Social Policy', mimeo. Washington, DC: World Bank.

Murray, C. (1984) Losing Ground: American Social Policy 1950-1980. New York: Broadway Books.

Narayan, D. and Ebbe, K. (1997) 'Design of Social Funds', Discussion Paper No. 375. Washington, DC: World Bank.

Perrett, H. and Lethem, F. (1980) 'Human Factors in Project Work', World Bank Staff Working Paper No. 397. Washington, DC: World Bank.

Pritchett, L. (2005) The Political Economy of Targeted Safety Nets. Washington, DC: World Bank.

Rawlings, L. (2004) A New Approach to Social Assistance: Latin America's Experience with Conditional Cash Transfer Programs. Washington, DC: World Bank.

Redwood, J. (1993) World Bank Approaches to the Environment in Brazil: A Review of Selected Projects. Washington, DC: World Bank.

Rich, B. (1994) Mortgaging the Earth. London: Earthscan.

Salmen, L. (1987) Listen to the People: Participant Observation Evaluation of Development Projects. Oxford: Oxford University Press.

Skoufias, E. (2005) 'PROGRESA and its Impacts on the Welfare of Rural Households in Mexico', Research Report No. 139. Washington, DC: International Food Policy Research Institute.

Stewart, F. (1985) Planning to Meet Basic Needs. London: Macmillan.

Subbarao, K. (1997) Safety Net Programs and Poverty Reduction: Lessons from Cross Country Experience. Washington, DC: World Bank.

Wade, R. (1997) 'Greening the Bank: The Struggle over the Environment, 1970-1995', in D. Kapur, J. Lewis and R. Webb (eds) The World Bank: Its First Half Century. Vol. 2: Perspectives (pp. 611-734). Washington, DC: Brookings Institution.

Wade, R. (2001) 'Making the World Development Report 2000: Attacking Poverty', World Development 29(8): 1435-41.

Wade, R. (2002) 'US hegemony and the World Bank: The Fight over People and Ideas', Review of International Political Economy 9(2): 215-43.

Williamson, J. (1990) 'What Washington Means by Policy Reform', in J. Williamson (ed.) Latin American Adjustment: How Much Has Happened? (pp. 5-20). Washington, DC: Institute for International Economics.

World Bank (1980) World Development Report. Washington, DC: World Bank.

World Bank (1990) World Development Report 1990: Poverty. Washington, DC: World Bank.

World Bank (1994) Averting the Old Age Crisis. Washington, DC: World Bank.

World Bank (2000) Social Protection Strategy Paper: From Safety Net to Springboard. Washington, DC: World Bank.

World Bank (2001) World Bank Report 2000/2001: Attacking Poverty. Washington, DC: World Bank.

World Bank (2005a) Empowering People by Transforming Institutions: A Strategy and Implementation Plan for Social Development in Bank Operations. Washington, DC: World Bank.

World Bank (2005b) Putting Social Development to Work for the Poor: An OED Review of World Bank Activities. Washington, DC: World Bank. 
World Bank (2005c) World Development Report 2006: Equity and Development. Washington, DC: World Bank.

World Bank (2005d) 'Arusha Statement', paper presented at the Conference on New Frontiers of Social Policy: Development in a Globalizing World, Arusha, Tanzania, 12-15 December, accessed 19 March 2007, http://www.worldbank.org/socialpolicy World Bank (2005e) Annual Report 2005. Washington, DC: World Bank.

World Bank (2006a) From Schooling Access to Learning Outcomes: An Unfinished Agenda. Washington, DC: World Bank.

World Bank (2006b) Pension Reform and the Development of Pension Systems: An Evaluation of World Bank Assistance. Washington, DC: World Bank.

World Bank (2006c) 'World Bank President Assigns Responsibilities to Managing

Directors and Announces Organization Integration', press release, 27 June.

Yeates, N. (2001) Globalization and Social Policy. London: Sage.

RÉSUMÉ

Les Politiques Sociales dans la Banque Mondiale: Les Paradigmes et Défis

Les politiques sociales de la Banque Mondiale ont évolué de façon conceptuelle et pratique dans trois différentes directions: l'assistance sociale, la protection sociale et le développement social. Les services de l'assistance sociale et les besoins fondamentaux, ainsi que la protection sociale en tant que filets et garanties sociales, forment l'ensemble de ce qui est généralement considéré dans l'organisation comme étant la composante de la politique sociale. Le développement social reflète une vue plus large et plus fragmentée de la politique sociale. Récemment, les spécialistes bancaires ont tenté d'élargir la définition de la politique sociale au-delà du bien-être et de la protection, en se basant sur un discours académique de longue date dans ce dossier. Cependant, en tentant de poursuivre une vision plus holistique et plus étendue du développement de la politique sociale, ils risquent de rencontrer des obstacles internes majeurs. La réorganisation de la Banque, annoncée en juin 2006, pourrait limiter son indépendance et le versement aux spécialistes écologiques et sociaux, ce qui augmenterait le défi à surmonter.

RESUMEN

\section{Las Politicas Sociales del Banco Mundial: Paradigmas y Desafíos}

Las políticas sociales del Banco Mundial han evolucionado de manera conceptual y operacional en tres direcciones diferentes: la asistencia social, la protección social y el desarrollo social. Los servicios sociales y las necesidades humanas fundamentales, así como la protección social en forma de redes de seguridad y de garantías sociales, forman el pilar fundamental de lo que es generalmente contemplado dentro de la organización como el componente fundamental de la política social. El desarrollo social refleja una visión más amplia y más fragmentada de la política social. Los especialistas del Banco han intentado recientemente ampliar la definición de la política social más allá del bienestar y de la protección, basándose en un discurso académico consolidado desde hace algún tiempo. Dichos especialistas, que intentan elaborar una visión más extensa del desarrollo 
de la política social, corren el riesgo de encontrar obstáculos internos serios. Entre esos desafíos internos a los que tienen que hacer frente se encuentra la reorganización del Banco Mundial, anunciada en junio de 2006, la cuál puede servir para restringir la independencia de los especialistas sociales y del medio ambiente.

BIOGRAPHICAL NOTE

ANTHONy Hall is Reader in Social Planning at the London School of Economics and Political Science. His latest publications include: Social Policy for Development, with James Midgley (Sage, 2004); Global Impact, Local Action: New Environmental Policy in Latin America (Institute for the Study of the Americas, University of London, 2005); Amazonia at the Crossroads: the Challenge of Sustainable Development (Institute of Latin American Studies, University of London, 2000). Please address correspondence to: Anthony Hall, Department of Social Policy, London School of Economics, Houghton Street, London WC2A 2AE, UK. [email: a.1.hall@1se.ac.uk] 